\title{
Democratization of Public Policy Formulation Process About Revision Oil and Gas Act No. 22 of 2001 on Oil and Gas in Indonesian Legistilative Assembly Commission VII (2014-2017)
}

\author{
Khoirul Anam Gumilar Winata ", Samugyo Ibnu Redjo, Neneng Yani Yunigsih \\ Department of Goverment Science, Faculty of Social and Political Science, Padjadjaran University, Bandung, Indonesia
}

Email address:

khoirul16001@mail.unpad.ac.id (K.A. G. Winata)

${ }^{*}$ Corresponding author

To cite this article:

Khoirul Anam Gumilar Winata, Samugyo Ibnu Redjo, Neneng Yani Yunigsih. Democratization of Public Policy Formulation Process About Revision Oil and Gas Act No. 22 of 2001 on Oil and Gas in Indonesian Legistilative Assembly Commission VII (2014-2017). Journal of Political Science and International Relations. Vol. 2, No. 3, 2019, pp. 68-78. doi: 10.11648/j.jpsir.20190203.12

Received: June 23, 2019; Accepted: July 23, 2019; Published: October 17, 2019

\begin{abstract}
Oil and Gas Act No. 22 of 2001 is in the processing of revision, because Indonesian Legislative Assembly inquiry committee on the period of 2004-2009 to revise the oil and gas Act and the Constitutional Court Decision No. 36 / PUU-X / 2012 which are states that is oil and gas Act contrary to the Constitutional of Indonesia 1945 in Article 33. Oil and Gas Act was the revision process by the Commission VII of Indonesian Legislative Assembly from start period 2009-2014 up to Indonesian Legislative Assembly 2014-2019 period, which is until now has not completed to the process of revision. How to democratize the process of policy formulation in the Oil and Gas Act Revision Commission VII of Indonesian Legislative Assembly, has not been completed. Commission VII of Indonesian Legislative Assembly is the one who are responsible for the process of policy formulation revision of Oil and Gas Act No. 22 of 2001 should make the process of policy formulation with a democratic, and there is effective participation and equality of the vote, as well as their bright education and inclusion of adults so that the process of policy formulation revision of Oil and Gas Act No. 22 of 2001 running with democratic.
\end{abstract}

Keywords: Democratization, The Policy Formulation Process, Effective Participation, Equality of Vote, Clear Understanding, Inclusion of Adults

\section{Introduction}

Oil and Gas Act No. 22 of 2001 was the stage of the revision by Indonesian Legislative Assembly, incoming on National Act Program from 2010 to 2014, and the revised policy Act No. 22 of 2001 included in the National Act Indonesian Legislative Assembly from 2014 to 2019 period, in 2015, 2016 and 2017 Act included in the National Legislation Program a priority each year with a statement that the academic paper and the draft bill prepared by Indonesian Legislative Assembly, in this case by the Commission VII of Indonesian Legislative Assembly. Although it has been included in the priority each year in the National Legislation Program policy revision of Oil and Gas Act No. 22 of 2001, it has not been completed until now.
Indonesian Legislative Assembly held a discussion on the Act 22 of 2001, with the recommendation of Indonesian Legislative Assembly Inquiry Committee on Government Policy 2004-2009 Increase Fuel Price (Refined Fuel Oil inquiry committee of Indonesian Legislative Assembly). In the final report of the inquiry committee of Indonesian Legislative Assembly fuel delivered by the Plenary Session on 28 September 2009 gave the following recommendations to push the Government and / or Indonesian Legislative Assembly to immediately apply for the Oil and Gas replaces Oil and Gas Act No. 22 of 2001 and its implementing regulations. [1] Policy revision of Oil and Gas Act No. 22 of 2001 has been more than eight years of Indonesian Legislative Assembly Commission VII made especially Oil and Gas Act No. 22 of 2001 in the national Act on the agenda for 2010-2014 and the priorities of Indonesian Legislative Assembly the period 2014 
to 2019 but has not been completed yet until now.

Democratization associated with the process of change to expand the role of the public to participate in a government, state or governments are no longer seen as the sole actor in the implementation of governmental tasks. [2] The government is seen as the leading sector in the democratic process of governance that involves public participation. The government that has the function to make regulations or policies, involving public participation in the formulation of a policy and the extent to which governments involve community participation in the formulation of a policy.

Commission VII of Indonesian Legislative Assembly as an initiator of the policy formulation process of the revision of Oil and Gas Act No. 22 of 2001 do with a democratic, internal Commission VII and the community was involved, using the indicator in the democratization process of policy formulation, namely:

1. Effective participation

2. Similarities in voted

3. Getting a clear underestanding

4. To supervise the last of the agenda

5. The inclusion of adults. [3]

Researchers examining democratization in the policy formulation process of the revision of Act No. 22 of 2001, using the criteria; effective partisipation and equal vote, clear understanding and inclusion of adults, to see how far the democratization in the policy formulation process of the revision of Oil and Gas Act No. 22 of 2001.

In the effective participation criteria, will see how far the participation of the actors are involved with the policymakers. In a clear understanding of the criteria will see the extent to which actors who's have a comprehensive policy to see what policy alternatives proposed by the policy actors. And inclusion of adults, will see the extent to which the Indonesian Legislative Assembly open space for people to be involved in the policy formulation process of the revision of Oil and Gas Act No. 22 of 2001.

In the process of policy formulation revision of Act No. 22 In 2001, researchers will see the actors of policy and policy alternatives, for all activities that occur in the process of policy formulation is a series of activities carried out by the actor and the role of actors is crucial in formulating, consider the consequences of policies they make, and establish a Policy. Of the activity of the actor could see the benefit of that debate among policy makers actor.

The interests of the debate among policy makers actors in Indonesian Legislative Assembly Commission VII will look at alternatives and the emerging policy debate. The Alternatives Policy in this study will look at how the actors and policy makers identification and definition of alternatives policy, assess and choose policy alternatives. Policy actors should refer to the Constitutional Court decision No. 36 / PUU-X / 2012 and the 1945 Constitution, article 33, paragraph 2 and 3 on which the policy of the revision of Oil and Gas Act No. 22 of 2001.

In the process of policy formulation revision of Oil and Gas Act No. 22 of 2001 has not been completed, because of differences in interests between policy actors, and the extent of public involvement in the policy formulation process. The extent to which the democratization of the Commission VII DPR RI as initiator policy revision of Oil and Gas Act No. 22 of 2001 with the criteria; effective participation, education bright, and the inclusion of adults in the process of revision of Act No. 22 of 2001. In the process of policy formulation would see who the actors in the process of policy formulation policy revision of Act No. 22 of 2001, what are the policy alternatives proposed by actors policymakers, before eventually proposing policy alternatives that a draft policy proposals and passed into Oil and Gas Act No. 22 of 2001.

\section{Background}

In 1997, Indonesia experienced a prolonged economic crisis and widespread touching aspects of national life including politics, namely the revelation of President Suharto led Indonesia entered the reform era. From the economic aspect, a prolonged crisis has resulted in a high foreign debt, causing Indonesia must accept the help offered by the IMF (International Monetary Fund) with several requirements, including reforming the two sectors crucial for economic recovery, namely Electricity and Gas.

The following description in the book of OIL AND GAS by Suyitno in Political, Law and Industry: The Politics of Oil and Gas Industry Management Law Indonesia associated with the Energy Independence and Security in the National Economic Development:

A strong impetus for reforming the sector Electricity and Gas contained in clause 60th Letter of Intent IMF said, should government of Indonesia should be consistent for reform of the Law policies in a comprehensive manner in the oil and gas sector, and in accordance with the scheme MEFP (Memorandum of Economic and Financial Policies) in January 2000, the Indonesian government should immediately submit a draft Act on Electricity and Gas to Indonesian Legislative Assembly.

Bill as an elaboration of reforms in the oil and gas sector finally enacted on November 23, 2001 as Act No. 22/2001 on oil and gas mining replaces the previously applicable Act, Act No. 44 / Prp / 1960 on Oil and Gas Mining, Act No. 15 / 1962 on Oil Company's obligation to meet the domestic need and the Act 8/1971 of Pertamina. [4]

In Act 22 of 2001 the management of oil and gas in Indonesia include agencies or other bodies, namely, the Ministry of Energy and Mineral Resources, in this case the Directorate General of Oil and Gas, Development Management of Oil and gas, Development Management Downstream Oil and gas and Pertamina. General policies for Industry is now the authority of the Directorate General of Oil and Gas, regulation and supervision of various business entities carried out by the implementing agencies, the upstream sector by Development Management of Oil and gas and the downstream sector by Development Management Downstream of Oil and gas. [5] The activities are held from Upstream by the Government as the holder of mining rights, while the Downstream activities undertaken by the company after 
obtaining permission from the Government. So that's the function of government as a regulator, manager and supervisor to operate more effectively and efficiently then in Upstream activities formed the Executive Agency (BP Oil and gas). Pertamina as the state company changed its status to PT (Company Limited) through the Government Regulation No. 31 of 2003 on Form Transitional Pertamina Persero Being. In upstream activities, Pertamina same position with the investor (company) others, ie, as a contractor for Development Management of Oil and gas in the Cooperation Contract. Similarly in downstream activities, Pertamina same position with other companies under the coordination of Development Management Downstream of Oil and gas.

After the enactment of Act No. 22/2001, a reaction of various circles of society who are members of TEAM ASSEMBLY OF ACT AND HUMAN RIGHTS LEADER CENTER MUHAMMADIYAH doing Application Testing Oil and Gas Act No. 22 of 2001 on Oil and Gas, with No. Case 002 / PUU-I / 2003. [6]

In this petition, which petitioned for testing not only the material section or sections but overall, because it is regarded as contrary to Article 33 paragraph (2) and (3) 1945. Until the end date of 13 November 2012 born Constitutional Court Decision No. 36 / PUU -X / 2012 stating that several articles and explanations relating to the implementing agencies is contrary to the 1945 Constitution and not Lawly binding.

The demands of society regarding the Act No. 22 of 2001, so that the issuance of Constitutional Court Decision No. $36 /$ PUU-X / 2012 stating that several articles and explanations relating to the implementing agencies contrary to 1945 , shows that the lack of public involvement in the formulation of the Act 22 of 2001 on oil and gas.

Indonesian Legislative Assembly held a discussion on the Oil and Gas Act 22 of 2001, with the recommendation of Indonesian Legislative Assembly Inquiry Committee on Government Policy 2004-2009 Increase Fuel Price (Refined Fuel Oil inquiry committee of Indonesian Legislative Assembly). In the final report of the inquiry committee of Indonesian Legislative Assembly fuel delivered by the Plenary Session on 28 September 2009 gave the following recommendations to urge the Government and / or Indonesian Legislative Assembly to immediately apply for the Oil and Gas replaces Oil and Gas Act No. 22 of 2001 and its implementing regulations.

\section{Democratization Policy Formulation Process}

The state as an organization of power includes three main components namely, rulers, power relations, and omnipotence (the people). Democracy in the power relations do not take place freely, because power is limited by the government and people constitution, called constitutional democracy. [2]

Three main component democracy in a country that is; ruler, power relations, and omnipotence (the people). Where the government as the leading sector could make contact with the people running the government. People given the space to deliver the aspirations of the government's policy-making process, in the manner of executing in the Constitution.

Modern democracies see the interests of individual and group interests are recognized as legitimate and reasonable, so that these interests is reached then formed a container that is able to adopt all these interests, so that measures its achievements can be developed within the framework intact. The container is formed through a social contract that can be realized in two stages; First, the agreement is an agreement between the communities of individuals to form a society. Second, the government agreement is an agreement between the community to form a government. [2]

There are some criteria to see the development of democracy in a government in making policies:

1. Effective participation; all members should have equal opportunities and effective way to make their views known by the member-member, before the policy was created or implemented.

2. Equation vote; when made decicion in making policy, each member must have equal and effective opportunities to vote and the entire vote should be counted equally.

3. A Bright Education; each member shall have equal opportunities and effective way to learn the policies altiernatif.

4. Supervision of the agenda; each member shall have the exclusive opportunity to decide how and what issues discussed in the agenda.

5. The inclusion of adults; all or most adults menajadi permanent residents have the right to full citizenship, treat all equally politically. [3]

Formulation of policies as part of the public policy process is the most crucial phase for the implementation and evaluation of policies can only be implemented if the policy formulation phase has been completed, in addition to the failure of a policy or program within reach-purposegoal based largely on the imperfections refineries formulation stage. [7]

Formulation of public policy is a step in the policy process in which a government agenda issues to be forwarded in the form of public Act. [8] Formulation of policies that are part of the policy process, in which the policy issues on the agenda of the policy, are processed in policy formulation, and is set as a policy. Policy formulation is the most important stage in the process of policy formulation, as an initial step that policy set, before it is implemented and evaluated.

So important stages of policy formulation in determining the results issued or output to the public. Public policy formulation is the process of transforming inputs into outputs. If so, the formulation of public policy is political because of actors, interests, and the interaction of the actors become the main focus. [9] Policy formulation revision of Oil and Gas Act No. 22 of 2001 has not been completed to date for the interests of actors policymakers.

In understanding the policy formulation process need to understand the actors involved or the cast as well as in the process of formulating the policy, both official actors and 
actors who are not authorized. That in order to understand exactly who formulated the first policy should be understood properties of all cast fibers, part or what role they do, the authority or form of power that they have, and how they are interconnected and mutually supervise. [10]

James Anderson in Winarno (2012) stated, the formulation of policies on efforts to answer the question how an agreed alternative to the problems that developed and who participates. [10]

In policy formulation, policy alternatives is any part of the policy formulation process, aim to address policy issues with various policy alternatives offered by the actor's policymakers, who then selected the appropriate policy alternatives in policy issues.

The formulation of a comprehensive policy, how the actors in the policy formulation process should estimate the impact of policy proposals. In this case the Commission VII of Indonesian Legislative Assembly as an actor who has authority to decide the policy formulation process should estimate the impact of various proposals other policy actors in making the proposed draft policy revision of Act No. 22 of 2001.

Based on the above, the researchers came to the conclusion that the process of policy formulation is the most crucial stage in the process, because of the stage of the policy formulation process produces solutions to public problems which will then be endorsed by the government into public Act. But need further examination in the process of policy formulation is an activity that is not neutral from politics, so that policy formulation was a compromise of the actors who play a role in formulating policies to agree to choose an alternative in solving public problems.

Democratization policy revision process in this study will look at two aspects, first know the actors involved and the interaction of actors in the policy process revisions of the policy. Commission VII of Indonesian Legislative Assembly as a policy actor who became the initiator of the policy revision of Oil and Gas Act No. 22 of 2001 involving other actors in order to realize the democratization of the policy formulation process, and how the interaction of policy actors in the policy formulation process, as well as the extent of the involvement of other actors in the process of policy revision of Act No. 22 of 2001.

Second, the policy alternatives will see democratization with a view of policy alternatives proposed by the actors in the policy, the goal to address policy issues with various policy alternatives offered by the actor policy makers, policy makers will have to refer to the decision of the Court No. 36 / PUU-X / 2012, the 1945 Constitution, article 33, paragraph 2 and 3, as well as the estimated impact of the proposed policy. In this case the Commission VII of Indonesian Legislative Assembly as an actor who has the authority to decide in the process of policy formulation, and drafting the proposed revision of Act No. 22, 2001 which was later chosen the right policy alternatives in policy issues.

The process of policy formulation revision of Oil and Gas Act No. 22 of 2001 is a policy initiative of the Indonesian Legislative Assembly, namely the policy revision of Oil and Gas Act No. 22 of 2001 compiled by the Indonesian Legislative Assembly in this regard the Commission VII of Indonesian Legislative Assembly responsible for preparing draft academic paper and the draft Act. Revision of Oil and Gas Act No. 22 of 2001 entered in the National Act Program (Prolegnas) from 2015 to 2018 in Indonesian Legislative Assembly in the period from 2014 to 2019, Bill (the Bill) on Oil and Gas is a priority bill in the National Act Program.

The process of policy formulation revision of Oil and Gas Act No. 22 of 2001 through two stages, the first stage of the preparation, and the second stage of the discussion. The following scheme groove formation process of policy formulation revision of Oil and Gas Act No. 22 of 2001 on Oil and Gas:

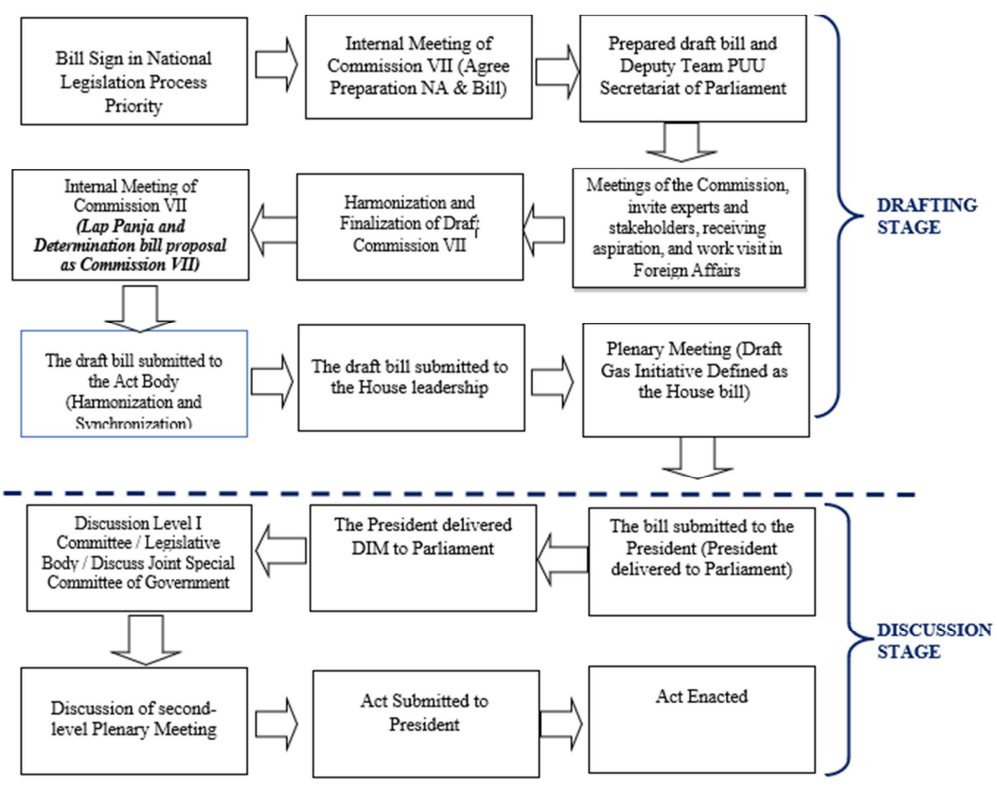

Commission Vii Of Indonesian Legislative Assembly (Processed Author, 2018)

Figure 1. Flow Scheme Bill Of Oil And Gas. 
The process of policy formulation revision of Oil and Gas Act No. 22 of 2001 new to the preparation phase, namely the draft Act - Act (bill) has been passed by Indonesian Legislative Assembly Commission VII which is then submitted to the Legislative body for harmonization and synchronization. Submission of draft Oil and Gas Act No. 22 of 2001 has been submitted to the Legislative body on April 27, 2017 and there has been no progress to date.

Description chairman of the editorial team of NA and the draft Commission VII (Bisman) as follows:

Draft Oil and Gas Act No. 22 of 2001 new to the preparation and in the preparation stage of a new up phase and synchronization in harmonization senate. Already from the date of 27 April 2017 submitted to the Act Body, but no follow-up or clarity again until now. [11]

Commission VII of Indonesian Legislative Assembly 2014-2019 period which is responsible for preparing academic papers and draft Bill No. 22 of 2001 has been included in the formulation stage from March 2015, and has already finished its work ratify the draft Act No. 22 of 2001. In the process of policy formulation revision of Act No. 22 In 2001, the Commission VII should make the process of policy formulation is democratic. Indicators to determine the extent of it can made by democratically or not, the implementation of a draft compilation In No. 22 of 2001 in Indonesian Legislative Assembly Commission VII.

Democratization described Robet Dahl see how far the policy formulation process of the revision of Act No. 22 of 2001, researchers adjust the criteria to see the extent of the democratization process in view of the study. Effective participation, a clear understanding, and inclusion of adults, researchers used three indicators to see the process of policy formulation revision of Act No. 22 of 2001.

Effective participation will examine the extent of the actor's policymakers in Indonesian Legislative Assembly Commission VII in which case each member of Commission VII of Indonesian Legislative Assembly be given an equal opportunity to participate actively both in providing an open view in the process of policy formulation revision of Act No. 22 of 2001 . In the effective participation inherently no vote of any actor equality policy makers in decision making, and given the same opportunity every member to vote in the decision-making.

Understanding of bright, will see how far each actor policymakers in this case every member of Commission VII of Indonesian Legislative Assembly have an understanding Comprehensive related policies are made, equal opportunities and effective way to learn about alternative policies and policy consequences, which will be visible from the alternative policy which appears in the process of policy formulation revision Act No. 22 of 2001.

The inclusion of adults, will see the extent to which the Commission VII of Indonesian Legislative Assembly involving public participation in the policy formulation process revision of Act No. 22 of 2001. From the start the stage for effective participation, a clear understanding of, and supervision agenda.

Researchers will discuss more in depth the democratization process of policy formulation revision of Oil and Gas Act No. 22 of 2001 which the Commission VII of Indonesian Legislative Assembly by using criteria, effective participation and equality of vote, clear understanding, and inclusion of adults. Judging from the policy actors are members of the Commission VII of Indonesian Legislative Assembly and the other actors involved, as well as policy alternatives in draft proposal of the actor's policymakers.

\section{Method}

This study discusses how democratization of the policy revision process Law No. 22 of 2001 concerning oil and gas studies in the House of Representatives Commission VII of the period 2014-2019, researchers knew of the democratization of the policy revision process regarding policy actors, and policy alternatives from policy revisions Law No. 22 of 2001 concerning Oil and Gas. The design or design of this study is seen from the analytical approach, the researcher uses a qualitative approach. In this study, the more emphasized is how the process is not merely the results.

Research using descriptive research methods with qualitative approaches emphasizes the analysis of quality. The data collected is not in the form of numbers, but the data comes from interviews, field notes, formal documents, and other official documents. So that the main objective of this qualitative research is to describe the empirical reality behind phenomena in depth, thorough, detailed and complete. Therefore the use of a qualitative approach in this study is to match, compare, and look for the red thread between empirical reality and the theory used by using descriptive methods.

In this study the authors used descriptive research methods. According to Nazir in the book the Research Methods are:

"Descriptive research method is a method in examining the status of human groups in an object, a system of thought, or in a class of events in the present. The aim of this research is to make a description, description or painting systematically, factually, and accurately of the facts, the characteristics and the relationship between the phenomena under investigation". [12]

By using descriptive research methods, researchers can describe the object of research can also highlight more specifically. So that certain knowledge can be explained in more detail and become valuable research for the development of theoretical concepts.

Informants are selected purposively or based on specific objectives that are closely related to the data that the researcher wants to obtain. Sugiyono that "the determination of the data source interviewed was done purposively, which was chosen with certain considerations and objectives". [13]

The selected informants came from various parties, policy actors in the revised policy of Law No. 22 of 2001 
concerning Oil and Gas, which was considered to know and have information relating to the problem of this research. The list of informants is as follows:

1. Member of the House of Representatives Commission VII

2. Expert Staff of the House of Representatives Commission VII

3. Civiel Society Organization

Data processed in this study comes from primary data and secondary data. Primary data is data that is directly recorded in the field such as through in-depth interviews with informants and which can be obtained through observations made by the researchers themselves. Meanwhile, secondary data is processed data or data that have been officially published obtained through the study of literature, documents, legislation, and other relevant institution archives.

Data collection techniques in qualitative research are divided into 4 (four) types of strategies, namely observation, interviews, documents, and visual images. The research instruments in this study were the researchers themselves using tools such as voice recorders, visual recording devices, stationery, and lap top to store research data. Sugiyono "in qualitative research, the research instrument or tool is the researcher itself". [13] Therefore researchers as instruments must also be validated to what extent qualitative researchers are ready to carry out research which then goes into the field. Qualitative researcher as a human instrument, serves to determine the focus of research, choose informants as sources of data, conduct data collection, assess data quality, analyze data, interpret data and make conclusions on everything.

Data analysis was carried out using the analysis process according to Miles and Huberman, namely data reduction, data presentation, and conclusion / verification. According to Miles and Huberman in Ulber Silalahi (2012: 339), the three activities flow together. Occur simultaneously which means data reduction, data presentation, and conclusions / verification as something intertwined is a cycle and interactive process when before, during, and after collecting data in parallel form to build general insights called "analysis". [14] The steps are as follows:

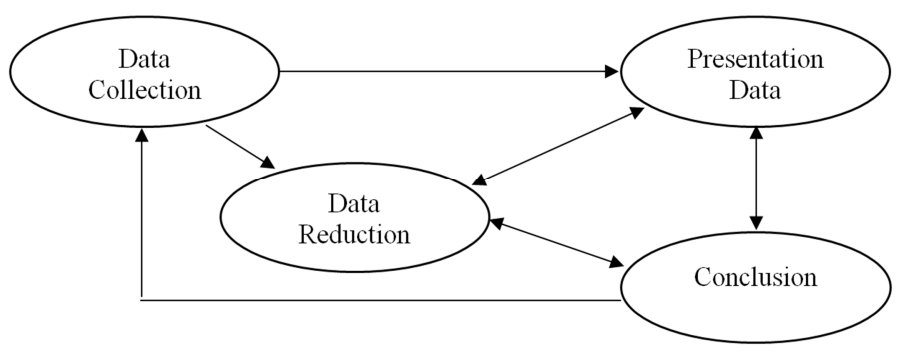

Source: Miles \& Huberman (1992: 20) in Silalahi (2012: 340).

Figure 2. Interactive Analysis Techniques.

In the research, valid, reliable, and objective research data are needed. So researchers are required to check the accuracy and credibility of the results of the research, namely by checking repeatedly and ensuring that the research data remains in line with the concepts and theories used. In the process of this research, the author examined the validity and reliability of the data by using triangulation techniques, namely examining data by comparing other data, with information from other researchers, or checking and cross-checking other sources.

This triangulation method is carried out both from the side of informants, data sources, data collection techniques, and research instruments as illustrated in the chronology of field research. After that, the writer still needs correspondence with the informant to triangulate the author's assumption. In the end, the data is considered valid when there is no difference between what is reported by the author and what actually happened to the object of research.

\section{Discussion}

\subsection{Effective Participation and Equal Vote in the Policy Formulation Process of the Revision of Oil and Gas Act No. 22 of 2001}

House of Representatives of the Republic of Indonesia
(DPR) Commission VII in this case Indonesian Legislative Assembly as an institution responsible for drafting the Bill No. 22 of 2001 on Oil and Gas. Effective participation and equality of vote of every member of Commission VII of Indonesian Legislative Assembly is one indicator that the process of policy formulation revision of Oil and Gas Act No. 22 of 2001 be democratic. What is meant by the effective participation and equality of vote here is the same opportunity to participate actively both in providing an open view and control the agenda in the process of policy formulation revision of Act No. 22 of 2001. In that effective participation in the inherent similarities vote of each actor's policymakers in making decisions.

Commission VII of Indonesian Legislative Assembly numbered 46 members, consisting of 10 factions ie, the fraction of the PDI-P has 9 members, the Golkar Party faction were 8 members, the fraction of Gerindra amounted to 7 members, Democratic factions consist of 5 members, PAN faction consists of 4 members, faction PKS consists of 3 members, the PPP faction consists of 3 members, totaling 3 Nasdem Party faction member, the PKB faction numbering two members, and the party faction Hanura numbered 1 member. [15]

The phenomenon of the field that researchers have found, in the process of policy formulation revision of Oil and Gas Act 
No. 22 of 2001 every member of Commission VII of Indonesian Legislative Assembly has the right to give an opinion, but every member will be a view of fellow members of the faction in giving a view to the problems and policies fraction, the views expressed each individual a reflection of the view of the faction. With the concept of the mechanism to provide the views of members of Commission VII made, the dominance of the interests of factions of political parties in this case is very thick. Each member in the same faction, giving personal views diinternal faction, which then formed the view fraction.

Furthermore, each fraction is given an equal opportunity with other factions in giving views or in giving vote to give an attitude, even though the number of members in a fraction of the more than a fraction of the other with the concept of the mechanism of voting or views based faction considered equal to the fraction of the others.

The phenomenon indicates the role of policy actors in this case members of Commission VII is not relevant to the theory of equality of votes for each member who had the opportunity to express their opinions in the commission meeting, because the mechanism of one faction will have the same view of looking at a particular issue.

Seeing the extent of participation of each member in his view can be seen from how many members were present at the meeting to join the process of policy formulation revision of Act
No. 22 of 2001 . The findings of the researchers in the field, often hampered because no quorum meeting or attendance is not more than half plus one the number of members of Commission VII, the phenomenon shows that the lack of active participation of each member of Commission VII in the process of policy formulation revision of Act No. 22 of 2001.

The following description and the NA chairman of the editorial team of draft Commission VII (Bisman):

The duration of the policy formulation process, because it is the presence of members of each meeting is often not a quorum, therefore the process of drafting this bill becomes old, from March 2015, a new finish on the Commission to Draft passed a bill in April 2017. [11]

The lack of active participation of every member of Indonesian Legislative Assembly Commission VII hinder the process of policy formulation is done effectively and completed quickly. Legislative function should cling to every member of Indonesian Legislative Assembly Commission VII in particular, the form of presence is a reflection of that member Commission VII of Indonesian Legislative Assembly in the process of policy formulation does not work effectively because of the participation of less than every member of Commission VII. The following agenda of the list of activities in Indonesian Legislative Assembly Commission VII of the policy formulation process of the revision of Oil and Gas Act No. 22 of 2001:

Table 1. Activities Of Formation Oil And Gas Act Commission VII Of Indonesian Legislative Assembly. Processed Writer 2018 (Document Commission VII of Indonesian Legislative Assembly from 2014 to 2019).

\begin{tabular}{|c|c|c|c|}
\hline NO & TIME & ACTIVITY & RESULTS \\
\hline 1 & March 24, 2015 & Internal meetings & $\begin{array}{l}\text { Commission VII of Indonesian Legislative Assembly agreed on will prepare a draft } \\
\text { academic paper (NA) into national Act in } 2015\end{array}$ \\
\hline 2 & May 19, 2015 & Internal meetings & $\begin{array}{l}\text { Commission VII of Indonesian Legislative Assembly agreed will hold a public } \\
\text { hearing (Public Hearing) with invited experts including; Prof. Mahfud MD, Kwik } \\
\text { Kian Gie, and ex-ex-Minister. }\end{array}$ \\
\hline 3 & July 3rd, 2015 & Internal meetings & Agreed on a draft drafting NA draft oil and gas Act. \\
\hline 4 & August 20th, 2015 & Internal meetings & $\begin{array}{l}\text { The fraction of each group in order to address issues that will be incorporated into } \\
\text { the NA, not later than } 27 \text { August. }\end{array}$ \\
\hline 5 & 2 September 2015 & Compilation Put oil and gas bill & - \\
\hline 6 & 15 September 2015 & Internal meetings & Agreed to propose national Act after the bill in 2016 \\
\hline 7 & August 25,2015 & Internal meetings & - \\
\hline 8 & $\begin{array}{l}25 \text { to } 27 \text { September } \\
2015\end{array}$ & $\begin{array}{l}\text { Preparation meeting after the } \\
\text { bill }\end{array}$ & 然 \\
\hline 9 & $\begin{array}{l}\text { November-December, } \\
2015\end{array}$ & FGD Working Visit & $\begin{array}{l}\text { Working visit to the local government and the FGD, expert and stakeholder in } 6 \text { area } \\
\text { (province of Riau, West Java, East Java, south of Sumatra and East Kalimantan) }\end{array}$ \\
\hline 10 & December 15, 2015 & RDPU & $\begin{array}{l}\text { RDPU bring experts (former director general of oil and gas), namely: Dr. Ir Rahmat } \\
\text { Sudibyo and Ir. Iin Arifin Takhyan. }\end{array}$ \\
\hline 11 & January 19, 2016 & Internal meetings & $\begin{array}{l}\text { Ask each faction to provide strategic issues more specifically. Submitted no later } \\
\text { than } 2 \text { February } 2016 .\end{array}$ \\
\hline 12 & February 4th, 2016 & RDPU & RDPU with universities (UI, UGM, ITS, UPN and Trisakti) \\
\hline 13 & 13 April 2016 & Internal meetings & $\begin{array}{l}\text { Receiving input to the oil and gas bill submitted } 8 \text { (eight) fraction,; PDIP, Golkar, } \\
\text { Gerindra, Democrat, PKB, PKS, Nasdem, Hanura. (PAN and PPP have not yet } \\
\text { submitted their inputs. }\end{array}$ \\
\hline 14 & 21 April 2016 & Internal meetings & - \\
\hline 15 & 27 April 2016 & Internal meetings & - \\
\hline 16 & May 19, 2016 & Internal meetings & - \\
\hline 17 & May 24, 2016 & FGD & FGD with PT. Pertamina \\
\hline 18 & June 20, 2016 & Internal meetings & - \\
\hline 19 & July 21, 2016 & Internal meetings & - \\
\hline 20 & 28 September 2016 & Internal meetings & - \\
\hline 21 & 28 September 2016 & Internal meetings & - \\
\hline 22 & - & Internal meetings & - \\
\hline 23 & - & Internal meetings & - \\
\hline 24 & 27 April 2017 & Internal meetings & \\
\hline
\end{tabular}


Of several phenomena that researchers have found that the Commission VII of Indonesian Legislative Assembly already taken steps in the process of policy formulation revision of Oil and Gas Act No. 22 of 2001 on oil and gas; by conducting internal meetings, public hearings, focus group discussions, and working visits. But the issue of effective participation of all members of Indonesian Legislative Assembly Commission VII was lacking and so many agendas that have been defined not eventuated and menglami setback in its realization.

The concept of vote equation requires stakeholder involvement in the course of each process of the government. Equation sound at the time the decision was made in making policy, each member must have equal and effective opportunities to vote and the entire vote should be counted equally.

Indicators are further democratization of the vote in the policy formulation process of mutual concern. Does that sound involved in the policy formulation process is executed with the principles of the equation or not? whether the existing sound have the same position, in the sense that there are no inaccuracies or undifferentiated vote in policy-making. Adage heard in a democracy is "one man one vote" where one person is guaranteed to have one vote. No one person should have more votes than the other and on the other hand there should be no one not votes at all.

Democratization can be said to have failed if there is no equality among stakeholders a vote in deciding policy. Vote equation in question here is not about the lack of diversity of views of each stakeholder, democratic precisely even maintain their color differences of thought and regarded as something that enrich democracy. However, the equation is sound in theory this is their equal opportunity among the respective stakeholders and obtain equal portions among the top everything.

Equation sound is a very important part and become democratic excellence in performing a policy-making process. Considered very important because noise equation becomes a manifestation of the value of individual equality. Democracy puts individual rights as a priority. It is also likely to be the hallmarks of democracy from the systemother. In a dictatorial system for example, the system does not recognize the term equation vote for individuals or civil society were never involved in the decision making process. All policy is only taken care of by the political elite.

In the context of this study, the equation is when the sound is finally made in policy formulation revision of Oil and Gas Act No. 22 of 2001, then each member of the Commission VII of Indonesian Legislative Assembly shall have equal and effective opportunities to vote. The entire vote should be counted as valuable. [3]

The phenomenon that researchers have found is the concept of a personal vote equation of Commission VII of Indonesian Legislative Assembly eventually disappear, because voting are colected each faction. An example of this in the revised Act submissions 22 of 2001 taken each faction. Second, the passage of an internal meeting of Indonesian
Legislative Assembly Commission VII can walk and stated that the indicator each faction quorum, in making such decicions. If there is a vote and involve personal House of Representatives Commission VII members, decisions are all based on the direction of the each faction.

The phenomenon of F-PPP and F-PAN that has not gave the suggestion or feedback on the Oil and Gas Act revision is not a form of damage principle of equality of vote in Indonesian Legislative Assembly Commission VII because nothing is holding them to give their views. That is, Indonesian Legislative Assembly Commission VII has provided input based on the views of each faction. Each faction providing input and consideration must have been in the disconnect in the internal factions or parties respectively. From the above table can also be seen that in the process of policy formulation revisisi revision of Oil and Gas Act No. 22 of 2001 all have the opportunity and the same values. Thus, the results showed that the principle of equality of vote is already well underway in the process of policy formulation related to the oil and gas Act.

Opinion submitted by each faction shows managed to make one of the pillars of democratization performing well because each faction had formed the arguments the importance of the revision of Oil and Gas Act No. 22 of 2001.

\subsection{Bright Education and Inclusion of Adult in Revised Policy Formulation Process of Oil and Gas Act No. 22 of 2001 on Oil and Gas}

Understanding of bright, will see how far each actor policymakers in this case any member or faction in the Commission VII of Indonesian Legislative Assembly have an understanding Comprehensive related policies are made, equal opportunities and effective way to learn about alternative policies and policy consequences, which will be visible of policy alternatives that arise in the process of policy formulation revision Act No. 22 of 2001.

The inclusion of adults, will see how far Indonesian Legislative Assembly Commission VII involves community participation in the process of policy formulation revision of Act No. 22 of 2001. How do people also understand from the beginning stages of participation in the formulation process of revision of Act No. 22 of 2001, a clear understanding about the issue - issues related to the discussion of revision of Act No. 22 of 2001.

A clear understanding refer to every member must have equal and effective opportunities to study the issues in this case the revision of Oil and Gas Act No. 22 of 2001 comprehensively thus can produce a number of relevant alternative policies. This is evident from the proposal, comments, and alternative policies proposed by each faction, which shows the extent of relevancy policy proposals and an alternate policies proposed by each faction, so that the proposal does not conflict with Article 33 UUD 1945, the Constitutional Court Decision No. 36 / PUU-X / 2012, and the aspirations of the people. As well as the extent of 
Commission VII of Indonesian Legislative Assembly involving public participation in the formulation process of revision of Oil and Gas Act No. 22 of 2001 on oil and gas.

See how far the understanding of each member or fraction in the Commission VII of Indonesian Legislative Assembly regarding the revision of Act No. 22 of 2001, researchers found the issues under discussion regarding the revision of Act No. 22 of 2001, which could then be an advanced indicator to determine the extent of understanding of members of House Commission VII RI. Here are the main points of matter Revised Act No. 22 of 2001:

a. Control of the Oil and Gas / Mining Rights Holder

b. Work Area Determination (Party sets, priority setting mechanisms and provisions to SOEs)

c. Institution of Upstream Oil and Gas

d. Institution of Downsream and Natural Gas

e. Sharing System Gas / Revenue-sharing

f. Utilization and Cost Recovery System

g. Alternative region of Oil and Gas

h. Oil and Gas Reserves Fund (Petroleum Found)

i. DMO (Priority Needs of the Interior)

j. Fuel Subsidy / fuel price policy

k. Strengthening Oil and Gas BUMN PT. Pertamina

1. Empowerment Producer Region / enterprises

m. Participating Interest (PI)

n. Enhancement Goverment Income

o. Guarantee the Neighborhood Restoration in mining areas

p. Institutional (Regulator) Natural Gas

q. Conditions and mekanism Guidance and supervision. [15]

Of the 17 issues under discussion in the revision of Act No. 22 of 2001, there are several issues that become an issue or a public concern, namely; Determination of Work Areas, Institutional Upstream Oil and Gas, exploitation and Cost Recovery System, and Strengthening Oil and Gas BUMN PT. Pertamina. The four issues of special concern to policy makers actor. [11]

There are ten factions contained in the Commission VII of Indonesian Legislative Assembly; F-PDI-P, Golkar F, FGerindra, F-PAN, F-PKS, F-PPP, F-Democrat, F-PKB, FHanura, and F-Nasdem. Ten factions officially all give their views in the form of documents, except the F-PAN and FPPP did not give his views on the revision of Act No. 22 of 2001. Looking at the extent of understanding of the factions in Indonesian Legislative Assembly Commission VII of the Revised Oil and Gas Act No. 22 of 2001 researchers look of proposals or views provided by each of the factions by relevancy policy proposals or responses proposed by any faction of the revision of Oil and Gas Act No. 22 of 2001 that the proposal does not conflict with article 33 of the 1945 Constitution, the Constitutional Court Decision No. $36 /$ PUU-X / 2012, and the main points of the material that became a public issue.

F-PDI-P already understand the whole problem of the revision of Act No. 22 of 2001, as an institution to regulate the activities of Upstream Oil and Gas Special Task Force was formed so that management of oil and gas are not berntentangan with the decision of the Constitutional Court No. 36 / PUU-X / 2012, as well as concern about the problem for the overseeing oil and gas upstream sector. Determining the concession system using a sharing system and strengthening state-owned PT. Pertamina to provide new working areas and provides long working area to SOEs Gas (PT. Pertamina). [16]

F-Golkar has given idea the principal subject in detail referring to several articles of the draft proposals, such as point zoning the work done by the Government (represented by the Minister of Energy and Mineral Resources) set out in Article 8, paragraph (2) draft oil and gas Act. Provide new proposal to establish a special state enterprises for implementing a mining concession by combining kompenen institutions Financial Services Authority, Bank Indonesia and Pertamina. Additionally provide corroboration for Pertamina to take over management of upstream oil and gas. [17]

F-Gerindra not focus on the work area in focus is the institutional system upstream oil and gas, which in this case combines main task of Special Unit Force Oil and gas and Pertamina to create a new state-owned enterprises (SOEs Oil and gas) which then holds the mining rights. The Oil and Gas SOE become single agent in the management of oil and gas, which includes arranged therein that represesntatif structure composition of some institutions (ministry of Human resource, ministry of SOE, Ministry of Finance, Bappenas). [18]

F-Democrats give feedback on the revision of Oil and Gas Act No. 22 of 2001 in the determination of the Work Area is determined by the president upon the recommendation of relevant ministries and clarify each chapter arrange to editorial regarding institutional and Gas Upstream Oil and Gas of the work contract. Disclose information to the public regarding cost recovery to the exploration or exploitation of the working area. Not explicitly considered the position of SOEs Pertamina Gas in this regard in its response. [19]

F-PKB in principle stressed on the role of the state in mastering and has oil and gas resources, managing the governance of oil and gas, and provision for SOEs delegeasi Oil and gas to manage oil and gas governance. Propose the use of oil and gas management system for results or service contract when SOEs have limitations in managing the Work area. Emphasizing transparency of cost recovery in the management of oil and gas by SOEs or other business until. [20]

F-PKS indirectly provides employment outlook areas that's determination in the hands of the government in this regard ministry of Human resources. In the Oil and Gas Upstream institutions managed by the Special SOEs in both the upstream and downstream sectors, management in working area of special priority given to the state-owned enterprises of oil and gas, and promoting transparency and accountability for funds Cost Recovery countries wich are coming out from the goverment. [21]

F-Nasdem looked sovereignty of natural resources of oil and gas held by both state policy and regulation. Holders 
handed to the state oil and gas governance company, using the results in it's management system, can make cooperation with national and foreign investors, so the pattern relation is Business to business. [22]

F-Hanura see Oil and gas governance administered by the state through the State Owned Enterprises (SOEs) in upper level management, by using a system of production sharing contracts, each contract of cooperation must be approved by Indonesian Legislative Assembly. F-Hanura indirectly view the strengthening of state enterprises in the management of oil and gas should be done, although it does provide SOE proposals which will then manage the governance of oil and gas. [23]

Researchers looked at eight factions give proposals or comment on the revision of Oil and Gas Act No. 22 of 2001 on oil and gas, all generally understand the root causes of why this Act in the revision, namely that Oil and Gas Act No. 22 of 2001 had violated the Constitution, the Constitutional Court Decision No. 36 / PUU-X / 2012, the state must sovereign on assets held in this case oil and gas. The second equation is, the new and old working areas has given to the Oil and Gas SOEs to managed, then whether are manage by themeself or cooperation with other business entities.

Governance Institutional oil and gas in this case the Upstream Oil and Gas in the hands of the government, but it is technically governance Institutional Gas Upstream mining there are still some view, that of the F-PDI-P was formed Special Unit of the Upstream Oil and Gas. Another view of the F-Golkar and F-Democrats who have the same view, namely, the Special SOE composed of representatives of the Financial Services Authority institutions, Bank Indonesia and state-owned oil and gas to regulate Institutional governance Upstream Oil and Gas, and made a special Act related to the Special SOE.

Gas management concession system all the same fraction opinion, that the exploitation of oil and gas exploration or exploitation either by SOEs with the Production Sharing Contract system, namely; if SOEs are not able to manage to be working with both the investor owned companies or other business entities. All the same faction views related to cost recovery should be informed to the public about its use is transparent, because there a lot going on markup budget and corruption.

Researchers looked at all the factions understand the main points of discussion of the revision of Oil and Gas Act No. 22 of 2001, with the dialectical process between factions within sight of an institutional governance issues Upstream Oil and Gas, oil and gas exploitation, feedback regarding cost recovery and the strengthening of state-owned companies and gas.

In fulfillment of the pillars of democracy, Fraction - the fraction of each political party submitted its opinion on the content and the desire of each member in the commission VII. eight factions filed a bill in accordance with the interests of each party. From the data the researchers get that eight factions have put forward the input to draft oil and gas Act. Only two factions have not provided submissions revision of
Oil and Gas Act No. 22 of 2001 which is the National Mandate Party (PAN) and the Development Unity Party (PPP). It does not diminish the essence of democracy in the formulation process of revision of Act No. 22 of 2001, as a space for F-PAN and F-PPP already dberikan by the Commission VII of Indonesian Legislative Assembly to make a proposal or response, and it is the political choice of the F-PAN and F -PPP.

Commission VII of Indonesian Legislative Assembly also public participation in the formulation process of the revision of Oil and Gas Act No. 22 of 2001, involving academics, experts, heads of regional, state-owned oil and gas, and related stakeholders in the agenda of FGD and Public Hearing, to provide input and insight to every member Commission VII of Indonesian Legislative Assembly. In the process of democratization in the policy formulation process, the inclusion of adults already undertaken by the Commission VII of Indonesian Legislative Assembly.

\section{Conclusion}

Conclusion of Democratization The process of policy formulation regarding the revision of Law No. 22 of 2001 in the House of Representatives Commission VII does not work, there is no room for people to participate directly in the policy formulation process so that monitoring of the agenda cannot be carried out optimally. Resulting in the process of formulating a revised policy of Law No. 22 of 2001 until now has not been completed.

\section{Suggestion}

To increase the participation of each member of the House of Representatives Commission VII, the need for transparency in the presence of each agenda of the meeting or policy discussion activities, there must be strict sanctions for every member of the DPR who does not follow the agenda of the discussion. The House of Representatives Commission VII must provide massive education to the general public by publishing the results of each discussion of meetings and proposals from each faction. The creation of a special forum by the House of Representatives Commission VII for community groups who wished to provide input or suggestions regarding the revision of the policy of Law No. 22 of 2001 .

\section{References}

[1] http://www.dpr.go.id/id/berita/lain-lain/2009/sep/03/672/dprsetujui-bahas-ruu-migas-pada-periode-2009-2014 (Accessed on Thursday, 14 August 2014).

[2] Redjo, Samugyo Ibnu. 2012. Transformasi Manajmen Pemerintahan. Bandung: AIPI.

[3] Dahl, Robeth, 2001. Demokrasi: Menjelajahi Teori dan Praktek Demokrasi Secara Singkat, Jakarta: Yayasan Obor Indonesia. 
[4] Patkosukismo, Suyitno. 2011. MIGAS Politik, Hukum dan Industri: Politik Hukum Pengelolaan Industri Migas Indonesia dikaitkan dengan Kemandirian dan Ketahanan Energi dalam Pembangunan Perekonomian Nasional. Jakarta: PT Fikahati Aneska. p: 13-14.

[5] July July Commander Saragih berkas.dpr.go.id/pengkajian/files/buku_tim/buku-tim-9.pdf (accessed on Thursday, 14 August 2014).

[6] Bakhri, Syaiful, 2013. Migas untuk Rakyat: Pergulatan Pemikiran dalam Peradilan Mahkamah Konstitusi, Jakarta: Grafindo. p: 32.

[7] Wibawa, Samodra. 2011. Politik Perumusan Kebijakan Publik Yogyakarta: Graha Ilmu.

[8] Lester and Stewart: in Kusumanegara, Solahudin. 2010. Model and Actor. In the Policy Process Public Policy. Yogyakarta: Gava Media. p: 86.

[9] Raymond Bauer: in Solichin Abdul Wahab. 2002. Policy Analysis (From formulation to Preparation Models of Implementation of the policy). Jakarta: Earth Literacy. p: 33.

[10] Winarno, Budi. 2012. Public Policy, Theory, Process, and case studies. Yogyakarta: CAPS.

[11] Results interview with the chairman of the editorial team of draft Act No. 22 of 2001 Mr. Bisman (interview conducted 27 April 2018).

[12] Nazir, M. 1998. Metode Penelitian. Jakarta: Bina Aksara.

[13] Sugiyono, Prof. Dr. 2012. Metode Penelitian Kuantitatif Kualitatif dan R\&D. Bandung: ALFABETA.

[14] Ulber, Silalahi. 2012. Metode Penelitian Sosial. Bandung: Unpar Press.
[15] (Document Commission VII of Indonesian Legislative Assembly from 2014 to 2019).

[16] Processed Data Researcher, about views or proposals PDI P against the draft oil and gas Act. File Expert Commission VII of Indonesian Legistilative Assembly. 2017.

[17] Processed Data Researcher, of the Golkar faction views or proposals to the draft oil and gas Act. File Expert Commission VII of Indonesian Legistilative Assembly 2017.

[18] Processed Data Researcher, about the outlook or Gerindra Fraction proposal to draft oil and gas Act. File Expert Commission VII of Indonesian Legistilative Assembly. 2017.

[19] Processed Data Researcher, about the outlook or the Democratic Party to the Draft Proposed Oil and Gas Act. File Expert Commission VII of Indonesian Legistilative Assembly. 2017.

[20] Processed Data Researcher, about the outlook or PKB to the Draft Proposed Oil and Gas Act. File Expert Commission VII of Indonesian Legistilative Assembly. 2017.

[21] Processed Data Researcher, about the outlook or the PKS faction to the Draft Proposed Oil and Gas Act. File Expert Commission VII of Indonesian Legistilative Assembly. 2017.

[22] Processed Data Researcher, about the outlook or Nasdem Party to the Draft Proposed Oil and Gas Act. File Expert Commission VII of Indonesian Legistilative Assembly. 2017.

[23] Processed Data Researcher, about the outlook or Hanura faction to the Draft Proposed Oil and Gas Act. File Expert Commission VII of Indonesian Legistilative Assembly. 2017. 